\title{
Loss Assessment caused by Economically Important Pea (Pisum sativum L.) Diseases and their Management in Hills of Doda (Jammu \& Kashmir) under Field Condition
}

\author{
A.C. Jha, Sonika Jamwal, Reena*, Anil Kumar and Parmendra Singh \\ Advanced Centre for Rainfed Agriculture, SKUAST-Jammu, \\ Dhiansar, Bari Brahmana - 181133, India \\ *Corresponding author
}

Keywords

Economically Important Pea (Pisum sativum L.), Hills of Doda

Article Info

Accepted:

04 April 2019

Available Online:

10 May 2019
A B S T R A C T

Experiments were conducted at Sartingal farm of Regional Horticulture Research Substation (RHRSS) Bhaderwah, Doda, SKUAST-Jammu in randomized block design with eight treatments replicated thrice to assess the losses caused by economically important diseases of pea viz., Ascochyta blight and powdery mildew of pea (Pisum sativum L.). Eight different fungicides and bioagents evaluated as foliar spray, recorded significant reduction against ascochyta blight and powdery mildew disease incidence with a concomitant significant increase in yield over control. Among the treatments, foliar spray with Hexaconazole @ $0.1 \%$ sprayed twice at 15 days interval was most effective in reducing the disease severity of Ascochyta blight (10.65\%) and powdery mildew (8.83\%). Percent reduction in disease incidence over control (42.08\% Ascochyta blight and $37.66 \%$ powdery mildew) was $74.69 \%$ and $76.55 \%$ respectively in Ascochyta blight and powdery mildew. Accordingly pea yield was also highest in this treatment $(99.78 \mathrm{q} / \mathrm{ha})$ which recorded $134.83 \%$ increase in pea yield over check $(42.49 \mathrm{q} / \mathrm{ha})$. This was followed by Carbendazim @ 0.1\% that recorded the disease severity of Ascochyta blight (12.74\%) and powdery mildew $(16.16 \%)$ and pea yield of $74.00 \mathrm{q} / \mathrm{ha}$.

\section{Introduction}

Pea (Pisum sativum L.) locally named as "matar" is one of the most important legume vegetables crops in India. It is grown for its edible seeds having growing season of at least five months duration. It belongs to the family (Fabaceae) Leguminosae, originated from common pea and is considered to be native of Ethiopia, the Mediterranean and Central Asia. Like other legumes, pea has high in protein and carbohydrates. It contains a high per cent of digestible protein $(7.2 \mathrm{~g} / 100 \mathrm{~g})$ of edible portion and good content of vitamins, like vitamins A $(139 \quad \mathrm{IU}), \quad$ vitamins $\quad B$ $(0.25 \mathrm{mg} / 100 \mathrm{~g})$ and vitamins $\mathrm{C}(9 \mathrm{mg} / 100 \mathrm{gm})$. It is also very rich in minerals such as phosphorus $\quad(139 \mathrm{mg} / 100 \mathrm{~g})$, magnesium $(34 \mathrm{mg} / 100 \mathrm{gm})$ and Iron $(1.5 \mathrm{mg} / 100 \mathrm{gm})$ (Bose et al., 1993). Mature seed contain $(100 \mathrm{~g}$ weight food) $10.9 \mathrm{~g}$ water, $22.9 \mathrm{~g}$ protein, $1.4 \mathrm{~g}$ fat, $60.7 \mathrm{~g}$ carbohydrate, $1.4 \mathrm{~g}$ 
fibre and 2.7g ash (Duke and Ayensu, 1985). It occupies a position of considerable importance because of its palatability in the form of vegetable curry along with many other vegetables and also widely used as pulses in daily diet. It is an excellent food source used either as a vegetable or soup or canned, frozen or dehydrated and pea straw is also a nutritious fodder. It is great agronomic value and also a profitable crop (Kudan, 2008). In crop rotation, it helps improvement of soil fertility and yield of succeeding crops (Rana and Sharma, 1993). Vegetative parts of pea are utilized as green fodder and haulm of pea are used as dry fodder. Pea plants have tremendous ability to fix atmospheric nitrogen through symbiosis. It is considered as an important cultivated legume next to soybean, groundnut and beans (Hules, 1994). Pea has high yield potential as compared to other pulse crop it is mainly cultivated in rabi season in plains and in the hills, this crop is grown in most part of the year including summer. The pea is grown on wide variety of soils ranging from light sandy to heavy clay soils. Economically pea is predominant export and cash crop in the world trade and represents about $40 \%$ of the total trading in pulses (Oram and Agcaoili, 1994). In India, vegetable pea is grown in about 0.37 million ha with annual production of 3.571 million tonnes. It is one of the major commercial vegetable crops of Bhadarwah, Doda, J \& K during summer season. The average yield of pea is quite low as compared to its yield potential. The crop is vulnerable to a large number of diseases. Among them powdery mildew and Ascochyta blight caused by Erysiphe pisi DC and Ascochyta pinodes, Ascochyta pinodella, Ascochyta pisi respectively are the major diseases occurring worldwide and can cause severe losses both in quality and quantity of fresh pods as well as dry seeds (Ek et al., 2005). Powdery mildew and ascochyta blight possess a continuous threat to its successful cultivation in crop growing areas of the J\&K state. It was reported for the first time in 1767 by Linnaeus. The pathogen causes up to 50\% losses and reduces pod quality (Nisar et al., 2006; and Dixon, 1987). In severely infected crop with powdery mildew, the reduction in pods per plant is estimated to be $28.6 \%$ (Rathi and Tripathi, 1994). Powdery mildew is an airborne fungus air currents spread the fungus locally and over long distances. Both conidia and ascospores could cause the disease, and all green parts of plant can be infected. It is a highly specialized obligate parasite and is distributed throughout all pea growing regions (Dixon, 1978). The disease is known to attack the plants on the lower most leaves near the soil and resistant spore store in seeds. The disease usually appear late in the season, reaching maximum intensity during the pod formation stage. The primary sign of powdery mildew is greyish white, powdery blotches on leaves. Usually, powdery fungal growth appears first on the upper leaf surface. Eventually the entire leaf may become covered with mildew. The symptoms include chlorotic or necrotic leaves, stems and fruits covered with mycelium and fruiting bodies of the fungus. The symptom is a white or gray, powdery growth on leaves and stem which will not usually kill a plant, however it may weaken plants. The lower leaves are the most affected but the mildew can appear on any part of the plant that shows above the ground. As the disease progresses, the spots get larger and thicker as a massive numbers of spores form and the mildew spread up and down the length of the plant that become diseased. Whereas rain controls the disease by washing off the spores and making them burst instead of germinating (Hargedorn, 1991). Rainfall does not favour the disease as it washes the conidiophores of the plants (Sivapalan 1993). The disease is most destructive in late sown crops (Falloon et al., 1990) or late maturing cultivars. The other most important disease in terms of acreage affected is Ascochyta blight. 
Yield losses of 5 to $15 \%$ are common in Saskatchewan when wet conditions persist. Yield losses up to $50 \%$ have occurred in research fields but losses of this magnitude are rare in commercial fields. Ascochyta infected seeds lead to high levels of disease in subsequent crop. Yields have increased 15 to $75 \%$ when fungicides are applied. Seed contamination over 5 or $10 \%$ is considered high in North Dakota and Saskatchewan, respectively, and seed treatment is recommended.

Ascochyta blight is a serious disease of pea worldwide. It was first described in Europe by Libert who named the pathogen Ascochyta pisi in 1830. Descriptions of other fungi causing very similar disease symptoms were later made by Berkeley and Bloxam in 1861 and Jones in 1927. Jones reported that isolates of Mycosphaerella pinodes and A. pisi could be distinguished by their appearance in culture.

More than one fungal species can cause this disease. All above ground portions and growth stages of pea plants are susceptible. Symptoms include the development of purplish black to brown spots or lesions on stems, leaves, tendrils, and pods. Black sporeproducing structures may form in these lesions. Pod lesions may become sunken. The fungi can overwinter in seed, infected crop residue, and in the soil. The disease was a constant threat in the United States until about 1915, when it declined with the shifting of the seed industry to areas in the West where the low rainfall, before and during harvest reduced the amount of infected seed. However, in years with unseasonal rainfall contaminated seed may still be found, and seed contamination remains a periodic problem. Management strategies include crop rotation, even though it has minimal impact reducing $A$. pinodes or $A$. pinodella, and using pathogen-free seed. Seed infection can negatively affect emergence and vigor, but seed-to-seedling transmission in the field is low. Ascochyta blight disease development is favored by temperatures between 20 to $21^{\circ} \mathrm{C}$ and high relative humidity. Disease normally will not develop at temperatures below $4^{\circ} \mathrm{C}$ and above $35^{\circ} \mathrm{C}$ or when periods of leaf wetness are less than $6 \mathrm{~h}$. The pathogens vary in length of incubation period; $A$. pinodes and A. pinodella are 2 to 4 days, compared with 6 to 8 days for A. pisi. Stem, crown, pod, and foliar diseases of pea are caused by a complex of Ascochyta pisi Lib. (teleom. Didymella pisi M.I. Chilvers, J.D. Rogers \& T.L. Peever), Mycosphaerella pinodes (Berk. \& A. Bloxam) Vestergr. (ana. Ascochyta pinodes L.K. Jones), and Phoma pinodella (L.K. Jones) Morgan-Jones \& K.B. Burch [syns. Ascochyta pinodella L.K. Jones, and Phoma medicaginis var. pinodella (L.K. Jones) Boerema]. The three organisms resemble each other closely, but are distinct species and difficult to distinguish based on symptoms. Each pathogen can overwinter in seed, infested crop residue, and in the soil. Ascochyta pisi Lib. is the type species of the genus Ascochyta. The Didymella sexual state is typically assigned to class Dothideomycetes (Ascomycota). Didymella pinodes (Berk. \& A. Bloxam) Petr. is the most taxonomically correct name for the sexual state of Ascochyta pinodes. The name most commonly favored by plant pathologists is the synonym Mycosphaerella pinodes. Chilvers et al., isolates of $D$. pinodes clustered with $D$. exigua (Niessl) Sacc., the type species for Didymella, and were distant from Mycosphaerella punctiformis (Pers.) Starbäck, the type species for Mycosphaerella. It appears that Didymella is a more correct generic assignment for "Mycosphaerella" pinodes. The fungus, $D$. pinodes, has recently been placed in a new combination as Peyronellaea pinodes (Berk. \& A. Bloxam) Aveskamp, Gruyter \& Verkley. Phoma pinodella is the third species 
in this pathogen complex. A sexual state for this fungus would most likely be in Class Dothideomycetes, since molecular-genetic analysis grouped representative isolates with D. pinodes. Although the sexual state has been observed, the putative teleomorph was not named. The asexual state also has a new name, Peyronellaea pinodella (L.K. Jones) Aveskamp, Gruyter \& Verkley. All parts of the pea plant can become infected by any of the three fungi causing Ascochyta blight but the pathogens are very difficult to distinguish based on symptoms in the field. Symptoms on pea include the development of purplish black to brown spots or lesions on stems, leaves, and pods. Black spore-producing structures may form on these lesions. Pod lesions may become sunken. Early symptoms (purplebrown irregular flecks) are first observed under the plant canopy on lower leaves, stems, and tendrils, where conditions are more humid. These flecks enlarge and coalesce, resulting in the lower leaves becoming completely blighted and falling off. Severe infections on the stem may lead to girdling near the soil line, which is known as foot rot. Typical foot rot lesions are purplishblack in colour and may extend above and below the soil line. Girdling lesions weaken the stem and can lead to lodging and yield loss. In addition to girdling foot lesions, black to purplish streaks may develop on stems. These are most conspicuous at the nodes, and may enlarge into brown or purplish irregularshaped areas anywhere between the root zone and 10 inches $(25.4 \mathrm{~cm})$ up the stem. Lesions may develop on pods under prolonged moist conditions or if the crop has lodged. Pod lesions are initially small and dark, but may become extensive and lead to early pod senescence. Pod spots are gray to purplish, lack concentric rings, and are sunken. Severe pod infection may result in small, shrunken or discoloured seed. Lesions caused by $A$. pisi differ from $M$. pinodes. A. pisi lesions are typically $\tan$ or brown in colour with a distinct dark brown margin and visible pycnidia within the lesion. Pycnidia will also develop in lesions caused by $M$. pinodes, but will be less obvious as they blend into the already dark lesion.

\section{Materials and Methods}

Experiments were conducted during summer cropping season 2013 and 2014 at Sartingal farm of Regional Horticulture Research Substation (RHRSS) Bhaderwah, Doda, SKUAST-Jammu in randomized block design with eight treatments replicated thrice to assess the losses caused due to economically important diseases viz., Ascochyta blight and powdery mildew of pea (Pisum sativum L.) using a susceptible variety. Eight different treatments were imposed viz., (T1) Hexaconazole @ 0.1\%, (T2) Copper oxychloride 0.3\%, (T3) Mancozeb @ 0.25\%, (T4) Cabendazim @0.1\%, (T5) Dinocap @ 0.1\%, (T6) Trichoderma viridae @ 0.4\%, (T7) Trichoderma harzianum @ 0.4\% and (T8) Check. The optimum dose of bio-agents was found to be 4-8 g/L and increased yield were reported (Khan et al., 2007). Two sprays were given to the crops in the whole experiment one spray was given at 40 DAS (Days After Sowing), the second spray was given at 55 DAS. Control plots were sprayed with water. Observations on the disease severity were recorded after first disease symptoms appear on the leaves. Maximum disease intensity was taken in natural condition in all two years. Disease intensity was recorded after 40 and 55 days of sowing of every spraying. The percent disease control (PDC) was calculated as per the standard formula (Mayee and Datar, 1986). Disease intensity was recorded after one week of every spraying and yield was also recorded after harvesting. The percentage of pea diseases i.e., Ascochyta blight and powdery mildew were observed visually. 


\section{Statistical analysis}

The data were subjected to analysis of variance (ANOVA) in a Completely Randomized Design after appropriate transformations as suggested by Gomez and Gomez (1984) before statistical analysis. The difference of two means between treatments exceeding Critical Difference (CD) value is significant (Panse and Sukhatme, 1978).

\section{Results and Discussion}

Percent ascochyta blight and powdery mildew intensity and yield data recorded for both the years were pooled and analyzed and the data presented in Table 1. Fungicides and bioagent application gave significant reduction in disease incidence; powdery mildew and ascochyta blight. Significant increase in yield over control was also recorded as evident from Table 1. Foliar spray of pea crop with hexaconazole $0.1 \%$ twice at 15 days interval, started at 40 days after sowing was most effective in which the severity of ascochyta blight and powdery mildew were $10.65 \%$ and $8.83 \%$ respectively, thus recording $74.69 \%$ and $76.55 \%$ reduction in disease severity over the check respectively (clearly depicted in
Fig. 1). Accordingly pea yield was highest in this treatment $(99.78 \mathrm{q} / \mathrm{ha})$, which recorded $134.83 \%$ increase in yield over the check (42.49 q/ha). This was followed by foliar spray of pea crop with carbendazim $0.1 \%$ two times at 15 days interval, started at 40 days after sowing, in which the severity of ascochyta blight and powdery mildew were $12.74 \%$ and $16.16 \%$ respectively, with a corresponding yields of $74.15 \mathrm{q} / \mathrm{ha}$. Mancozeb $0.25 \%$ too recorded yield $67.24 \mathrm{q} / \mathrm{ha}$, comparable to that of Carbendazim $0.1 \%$. The bio-agents Trichoderma viridae $0.4 \%$ and Trichoderma harzianum $0.4 \%$ were less effective in managing the ascochyta blight and powdery mildew diseases of pea, recording 33.33 and $36.08 \%$ Ascochyta blight and 31.00 and $33.24 \%$ powdery mildew disease incidence respectively.

In accordance with our results Basandra et al., (2013) evaluated different fungicides and highest yield was recorded in tubeconazole followed by hexaconazole, propiconazole and mancozeb. Gupta and Shyam (1998) reported best control of powdery mildew and rust with hexaconazole. They also recorded control of powdery mildew and rust with mancozeb.

Table.1 Percent disease severity of important pea diseases and their management in hills of Doda (J \& K) (Pooled data)

\begin{tabular}{|c|c|c|c|c|c|}
\hline \multirow{2}{*}{$\begin{array}{l}\text { S. } \\
\text { No. }\end{array}$} & \multirow{2}{*}{ Treatments with dose } & \multicolumn{2}{|c|}{ Disease severity (\%) } & \multirow{2}{*}{$\begin{array}{l}\text { Yield } \\
\text { (Q/ha) }\end{array}$} & \multirow{2}{*}{$\begin{array}{l}\text { Increase in } \\
\text { yield over } \\
\text { check }(\%)\end{array}$} \\
\hline & & $\begin{array}{c}\text { Ascochyta } \\
\text { blight }\end{array}$ & $\begin{array}{c}\text { Powdery } \\
\text { mildew }\end{array}$ & & \\
\hline $\mathrm{T}_{1}$ & Hexaconazole $0.1 \%$ & 10.65 & 8.83 & 99.78 & 134.83 \\
\hline $\mathrm{T}_{2}$ & Copper oxychloride $0.3 \%$ & 19.33 & 24.66 & 61.74 & 45.30 \\
\hline $\mathrm{T}_{3}$ & Mancozeb $0.25 \%$ & 16.00 & 21.0 & 67.24 & 58.24 \\
\hline $\mathrm{T}_{4}$ & Cabendazim $0.1 \%$ & 12.74 & 16.16 & 74.00 & 74.15 \\
\hline $\mathrm{T}_{5}$ & Dinocap $0.1 \%$ & 28.66 & 11.74 & 59.00 & 38.85 \\
\hline $\mathrm{T}_{6}$ & Trichoderma viridae $0.4 \%$ & 33.33 & 31.00 & 56.50 & 32.97 \\
\hline $\mathrm{T}_{7}$ & Trichoderma harzianum $0.4 \%$ & 36.08 & 33.24 & 52.49 & 23.53 \\
\hline $\mathrm{T}_{8}$ & Control & 42.08 & 37.66 & 42.49 & - \\
\hline & CD@5\% & 2.01 & 2.85 & 1.65 & \\
\hline
\end{tabular}


Fig.1

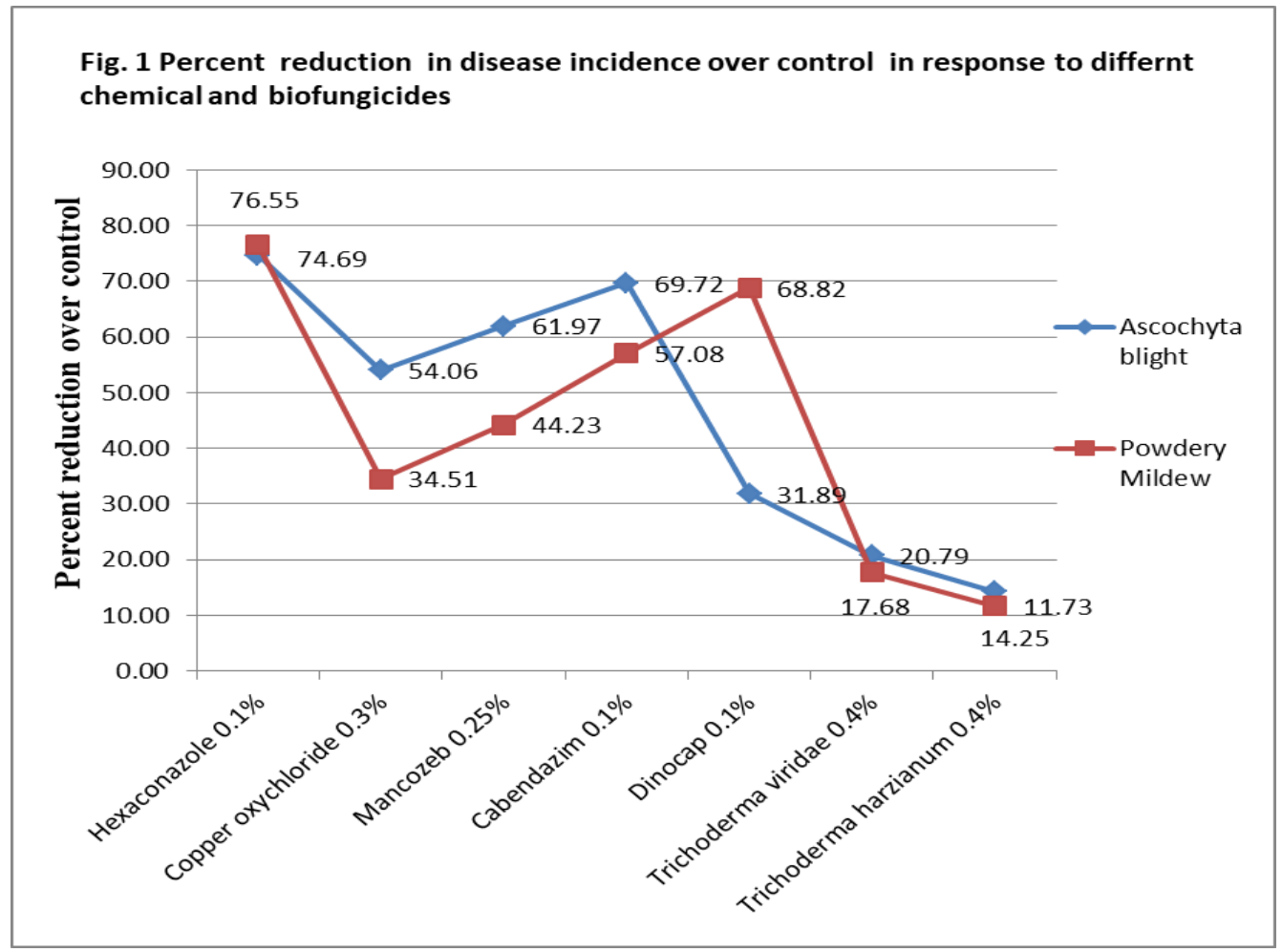

Sharma et al., (2002) reported the efficacy of bitertanol, hexaconazole, fenarimol, carbendazim, dinocap and wettable sulfur in controlling powdery mildew (E. pisi) on pea and also found hexaconazole to be highly effective in controlling the disease, followed by fenarimol and bitertanol. Tripathi et al., (2003) evaluated efficacy of dinocap, carbendazim, wettable sulphur, tridemorph, fenarimol, penconazole, chlorothalonil and difenoconazole against powdery mildew (caused by Erysiphe polygoni) and reported that tridemorph was most effective in reducing the disease severity. Bhardwaj and Sharma (1984) have reported five protectant sprays of bitertanol 25WP and triadimefon 25WP at 7 days interval to check the powdery mildew and obtained satisfactory pod yield.

Our results too corresponded with the results of these workers, wherein foliar spray of pea with hexaconazole $0.1 \%$ two times at 15 days interval, starting at 40 days after sowing is most effective in reducing the ascochyta blight and powdery mildew of pea, thereby increasing the yield.

\section{References}

Basandra, A.K., Basandrai, D., Mittal, P. and Sharma, B.K. 2013. Fungicidal management of rust, powdery mildew and Ascochyta blight in seed crop of pea. Pant Disease Research 28(1): 22.

Bhardwaj, S.S., Shyam, K.R. and Dohroo, N.P. 1987. Performance of pea varieties against powdery mildew in Himachal Pradesh. Vegetable Science 14(1): 55-57.

Bose, T.K., Som, M.G. and Kabir, J. 1993. Pea and Beans in Vegetable crops. Naga Prakash Calcutta. 6. pp. 550.

Dixon, G.R. 1978. Powdery mildews of vegetables and allied crops. In The powdery mildews. (Nm). Spencer, Editor. Academic Press, London. pp. 595.

Dixon, G.R., 1987. Powdery mildew of vegetables and allied crops. In The powdery mildew. 
D.M. Spencer (Ed.). Acad. Press. pp. 565.

Duke, J.A. and Ayensu, E.S. 1985. Medicinal plants of china. Reference publication. Inc. ISBN 0-917256, 20: 4.

Ek, M., Eklund, M., Von Post, R., Dayteg, C., Henriksson, T., Weibull, P., Ceplitis, A., Isaac, P. and Tuvesson, S. 2005. Microsatellite marker for powdery mildew resistance in pea (Pisum sativum). Hereditas, 142: 86-91.

Falloon, R.E., Me Eelich, A.F. and Scott, R.E. 1990. Effects of powdery mildew on vining and seed yields of garden peas. In: Proceeding of the 43rd New Zealand Weed and Pest Control Conference. NewZealand Weed and Pest Control Society: Palmerston North, NZ. pp 39-42.

Gupta, S.K. and Kumar A. 2008. Management of Erysiphe pisi through strobilurin and EBI fungicides. Indian phytopathology 61(2): 181-1.

Hargedorn, D.J. 1991. Handbook of pea diseases. Madison and Wisconsin.

Hules, J.H. 1994. Nature, composition and utilization of food legumes. In: Expanding the production and use of cool season food legumes. (Eds.): F.J. Muehlbauer and W.J. Kasir. Kluwer Acad. Pub. Dordrech, Netherland. pp. 77-97.

Khan,Y.M. and Iqbal M.A.M. 2008. Evaluation of various fungicides against powdery mildew disease on peas. Pakistan Journal of Phytopathology 20(2): 270-271.

Kudan, S.L. 2008. Snap bean and garden pea production guide. Office of Extension Services, Benguet State University, La Trinidad, Benguet. Revised Ed. 1-2.

Mayee, C.D. and Datar, V.V. 1986. Phytopathometry. Technical Bulletin-I, Marathawad Agricultural University,
Parbhani, India, 146 pp.

Nisar, M., Ghafoor, A., Khan, M.R. and Qureshi, A.S. 2006. Screening of Pisum sativum L. Germplasm against Erysiphe pisi Syd. Acta Biologica Cracoviensia Series Botanica 48(2): 33-37.

Oram, P.A. and Agcaoili, M. 1994. Current Status and Future Trends in Supply and emand of Cool Season Food Legumes. In: (Ed.): R.J. Summerfield, World Crops: Cool Season Food Legumes. Kluwer Acad. Pub. Dordrech, Netherland. pp: 3-49.

Panse, V.G. and Sukhatme, P.V. 1967. Statistical Methods for Agricultural Workers, Indian Council of Agricultural Research, New Delhi, p. 381.

Rana, K.S. and Sharma, S. K. 1993. Effect of rabi legumes on nitrogen economy and productivity of direct seeded upland rice. Crop Research Hisar, 6(1): 165-167.

Rathi, A.S. 1998. Role of leaf cuticular thickness in resistance against powdery mildew disease in peas. Indian Journal of Pulses Reearch, 11(1): 136-137.

Sharma, I.D., Nath, A., Gupta, S.K. and Shyam, K.R. 2002. Management of powdery mildew (Erysiphe pisi) through fungicides and persistence of bitertanol in pea (Pisum sativum). Indian Journal of Agricultural Sciences 72(9): 537-539.

Sivapalan, A. 1993. Effects of water on germination of powdery mildew conidia. Mycological Research 97: 71-76.

Tripathi, D.V., Chavhan, P.N., Raut, B.T., Ingle, Y.V. and Pandey, V.P. 2003. Efficacy of fungicides, botanicals and varietals resistance against powdery mildew of pea (Pisum sativum L.) PKV Research Journal 25(2): 102-105.

\section{How to cite this article:}

Jha, A.C., Sonika Jamwal, Reena, Anil Kumar and Parmendra Singh. 2019. Loss Assessment caused by Economically Important Pea (Pisum sativum L.) Diseases and their Management in Hills of Doda (Jammu \& Kashmir) under Field Condition. Int.J.Curr.Microbiol.App.Sci. 8(05): 170-176. doi: https://doi.org/10.20546/ijcmas.2019.805.021 